\title{
Supplementing Fertilizer Nitrogen Application to Irrigated Wheat at Maximum Tillering Stage Using Chlorophyll Meter and Optical Sensor
}

\author{
Bijay-Singh • Varinderpal-Singh $\cdot$ Yadvinder-Singh $\cdot$ H. S. Thind $\cdot$ \\ Ajay-Kumar $\cdot$ Satinderpal-Singh $\cdot$ O. P. Choudhary $\cdot$ R. K. Gupta $\cdot$ \\ Monika Vashistha
}

Received: 17 September 2012/Accepted: 29 January 2013/Published online: 16 February 2013

(C) NAAS (National Academy of Agricultural Sciences) 2013

\begin{abstract}
In the Indo-Gangetic plain in South Asia, fertilizer nitrogen (N) application to irrigated wheat in two split doses at planting and at crown root initiation (CRI) stages of the crop is the general recommendation. Farmers have a tendency to apply another dose of $\mathrm{N}$ at maximum tillering (MT) stage to avoid the risk of $\mathrm{N}$ deficiency. However, appropriate criteria to decide MT stage application of $\mathrm{N}$ are lacking. Field experiments were conducted for three seasons with four wheat cultivars to develop criteria for using a chlorophyll (SPAD) meter and an optical sensor (GreenSeeker ${ }^{\mathrm{TM}}$ ) for guiding MT stage N application. Application of $0,60,80,100$ and $120 \mathrm{~kg} \mathrm{~N}^{-1}$ in two equal split doses at planting and at CRI stage constituted the main plots. The two subplots consisted of applying 0 and $30 \mathrm{~kg} \mathrm{~N} \mathrm{ha}^{-1}$ at MT stage immediately after taking SPAD meter and GreenSeeker readings. Greenness of wheat leaves at MT stage was found to be a function of N applied at planting and CRI stages. Wheat grain yield at maturity was determined by the level of greenness of leaves at MT stage-whether measured by SPAD meter or GreenSeeker (expressed as in-season estimate of yield (INSEY) computed by dividing normalized difference vegetation index by number of days between planting and sensing). Grain yield response to $\mathrm{N}$ application at MT regressed against SPAD readings at MT revealed that an application of $30 \mathrm{~kg} \mathrm{~N} \mathrm{ha}^{-1}$ will increase wheat yield by 1.0 or $0.5 \mathrm{t} \mathrm{ha}^{-1}$ when color of the wheat leaves was equivalent to or less than SPAD value of 32.5 or 42.5 , respectively. Robust regression between grain yield response and INSEY values revealed that application of $30 \mathrm{~kg} \mathrm{~N} \mathrm{ha}^{-1}$ at MT will lead to a grain yield increase by 1.0 or $0.5 \mathrm{t} \mathrm{ha}^{-1}$ if INSEY values were found to be 0.005 or 0.011 , respectively. It should serve as an easy and useful criterion for applying a supplementary dose of fertilizer N at MT stage of wheat.
\end{abstract}

Keywords Fertilizer nitrogen - Irrigated wheat - Maximum tillering stage - SPAD meter · GreenSeeker optical sensor

\section{Introduction}

In South Asia, rice-wheat cropping system occupies about 13.5 million ha of cultivated land, extending across the Indo-Gangetic Plain (IGP) in Pakistan, northern India, and Bangladesh into the Himalayan foothills in Nepal [13]. As

Bijay-Singh $(\bowtie) \cdot$ Varinderpal-Singh .

Ajay-Kumar · Satinderpal-Singh · M. Vashistha

ICAR National Professor Project, Punjab Agricultural

University, Ludhiana 141 004, Punjab, India

e-mail: bijaysingh20@hotmail.com

Yadvinder-Singh · H. S. Thind · O. P. Choudhary · R. K. Gupta Department of Soil Science, Punjab Agricultural University, Ludhiana 141 004, India soils in the IGP are inherently low in levels of soil organic matter, wheat production is dependent on extensive fertilizer nitrogen $(\mathrm{N})$ use. The northwest and central parts of the IGP are among the most productive agricultural regions of the world [3] because both rice and wheat are grown under irrigated conditions. Farmers continue to intensify growing wheat as winter season crop due to high subsidies for power, fertilizer, and irrigation water, and well-developed production and marketing systems [23]. To wheat planted in rows, three to four irrigations are applied at the crown root initiation (CRI), maximum tillering (MT), flowering, and grain filling stages. All P and $\mathrm{K}$ and a half dose of $\mathrm{N}$ are applied at the planting of wheat. The remaining $\mathrm{N}$ is top-dressed in one or two splits at CRI and MT stages coinciding with irrigation events [18]. However, 
the efficiency of $\mathrm{N}$ fertilizer use tends to be around $50 \%$ in wheat [14]. The $\mathrm{N}$ that is lost, in addition to being an expense to the farmers, also has an environmental cost. As efficient $\mathrm{N}$ use is central to eco-efficiency in agriculture [12], it is important to identify nitrogen management practices that will allow high yields of wheat per unit area while minimizing environmental impact and being economically attractive to farmers.

To increase fertilizer $\mathrm{N}$ use efficiency in irrigated wheat, fertilizer $\mathrm{N}$ should be applied at growth stages when $\mathrm{N}$ needs of the crop are high so that applied $\mathrm{N}$ is least prone to losses from the soil to plant system. In northwestern India, wheat is grown with a blanket recommended dose of 120 (in Punjab) or $150 \mathrm{~kg} \mathrm{~N}^{-1}$ (in Haryana, western Uttar Pradesh) applied in two equal splits-basal $\mathrm{N}$ at land preparation or planting and $\mathrm{N}$ topdressing at CRI stage along with first irrigation [27]. In fact, it constitutes a general recommendation over a vast area under wheat in the Indo-Gangetic Plain (IGP) in South Asia. As N applications to irrigated wheat are linked to irrigation events, farmers often apply an extra dose of $\mathrm{N}$ with the irrigation even at MT stage to avoid the risk of $\mathrm{N}$ deficiency. On coarse-textured soils, application of $\mathrm{N}$ in three equal split doses at planting and along with first and second irrigation has been recommended. Chaudhary and Katoch [6] observed $14 \%$ higher grain yield of wheat when $\mathrm{N}$ was applied in three equal split doses rather than two.

Suitable criteria to determine the need of applying a dose of fertilizer $\mathrm{N}$ at MT stage is not available. The farmers have always used leaf color as a visual and subjective indicator of the need for $\mathrm{N}$ fertilizer. As plant growth reflects the total $\mathrm{N}$ supply from all sources, $\mathrm{N}$ status of leaves at any given time should be able to guide the need of fertilizer $\mathrm{N}$. The chlorophyll meter (SPAD meter) has emerged as a diagnostic tool which can indirectly estimate crop $\mathrm{N}$ status of the growing crop and help decide supplemental fertilizer $\mathrm{N}$ applications synchronized with the $\mathrm{N}$ needs of crop like rice and wheat [24]. Thus, the SPAD meter can help in establishing the need for $\mathrm{N}$ application at MT stage, which will largely depend on soil N supply, date of planting, and seasonal temperature. Unlike Chlorophyll meters, optical sensors, through measurement of visible and near-infrared spectral response from plant canopies, can take into account photosynthetic rates or the biomass production and expected yields for working out fertilizer $\mathrm{N}$ requirements. Spectral vegetation index-the normalized difference vegetation index (NDVI) recorded by optical sensors such as GreenSeeker ${ }^{\mathrm{TM}}$ — has been shown to be useful in indirectly estimating photosynthetic efficiency, productivity potential, and potential yield [21] and has been found to be sensitive to leaf area index, green biomass [20]. Raun et al. [22] found expected yield as determined from NDVI to show a strong relationship with the actual grain yield in winter wheat. The NDVI as recorded by optical sensor provides a measure of NDVI which can be used to work out an index of in-season estimate of yield (INSEY) as the measure of the daily accumulated biomass from the time of planting to the day of sensing [22]. INSEY can also help guide application of fertilizer $\mathrm{N}$ at MT stage of wheat. The experiments reported in this study were carried out to work out criteria for using SPAD meter and GreenSeeker $^{\mathrm{TM}}$ optical sensor for guiding fertilizer $\mathrm{N}$ application at MT stage of irrigated wheat in the northwestern IGP.

\section{Materials and Methods}

\section{Experimental Site}

The experiments were conducted during wheat seasons (November-April) of 2006-2007, 2007-2008, and 2009-2010 on a typic ustipsamment (Fatehpur loamy sand) at the experimental farm of the Punjab agricultural university, Ludhiana $\left(30^{\circ} 56^{\prime} \mathrm{N}, 75^{\circ} 52^{\prime} \mathrm{E}\right)$, located in the IndoGangetic alluvial plains in the state of Punjab, northwestern India. The area receives on average $800 \mathrm{~mm} \mathrm{yr}^{-1}$ rainfall, about $80 \%$ of which occurs from June to September. Mean maximum and minimum temperatures are 22.6 and $6.7^{\circ} \mathrm{C}$ during wheat (November-April) season. Soils are well drained. Table 1 shows the physical and chemical properties of soil samples $(0-15 \mathrm{~cm})$ from the three field sites.

\section{Experimental Design and Treatments}

The experiments were laid out in a split-plot design with three replicates. The $\mathrm{N}$ levels of $0,60,80,100$, and $120 \mathrm{~kg} \mathrm{~N} \mathrm{ha}^{-1}$ applied in two equal split doses-basally at planting of wheat and at CRI stage, constituted the main plots. The two subplots consisted of applying 0 and $30 \mathrm{~kg} \mathrm{~N} \mathrm{ha}^{-1}$ at MT stage immediately after taking chlorophyll meter and GreenSeeker optical sensor readings. The MT stage almost coincided with second irrigation to the crop. This treatment set allowed to study the response of $30 \mathrm{~kg} \mathrm{~N} \mathrm{ha}^{-1}$ applied at MT stage and its relationship with SPAD and optical sensor measurements.

\section{Crop Management}

Before planting wheat, the land was plowed twice to about $20 \mathrm{~cm}$ depth and leveled. Wheat was sown in rows $20 \mathrm{~cm}$ apart in 24-30 $\mathrm{m}^{2}$ plots in the 3 years. After seeding with a hand-drawn seed-cum-fertilizer drill, a plank was dragged over the plots to cover the seed. During the three wheat seasons, the cultivars tested were: PBW343 in 2006-2007, PB343 and WH542 in 2007-2008, and DBW17 and 
Table 1 Some properties of the soil $(0-15 \mathrm{~cm})$ at the experimental sites

\begin{tabular}{lllllll}
\hline Experiment conducted in & Sand $\left(\mathrm{g} \mathrm{kg}^{-1}\right)$ & Silt $\left(\mathrm{g} \mathrm{kg}^{-1}\right)$ & Clay $\left(\mathrm{g} \mathrm{kg}^{-1}\right)$ & $\mathrm{pH}^{\mathrm{a}}$ & $\mathrm{EC}^{\mathrm{b}}\left(\mathrm{dS}\left(\mathrm{m}^{-1}\right)\right)$ & $\mathrm{Organic} \mathrm{C}\left(\mathrm{g} \mathrm{kg}^{-1}\right)$ \\
\hline $2006-2007$ & 742 & 183 & 75 & 7.32 & 0.17 & 4.4 \\
$2007-2008$ & 780 & 160 & 60 & 7.14 & 0.16 & 4.1 \\
$2009-2010$ & 774 & 157 & 69 & 7.42 & 0.15 & 3.9 \\
\hline
\end{tabular}

a $1: 2$ soil/water

${ }^{\mathrm{b}}$ Electrical conductivity

PBW550 in 2009-2010. All P [26 kg P ha ${ }^{-1}$ as $\mathrm{Ca}\left(\mathrm{H}_{2} \mathrm{PO}_{4}\right)_{2}$ ] and $\mathrm{K}\left(25 \mathrm{~kg} \mathrm{~K} \mathrm{ha}^{-1}\right.$ as $\left.\mathrm{KCl}\right)$ were drilled below the seed at planting. The basal dose of $\mathrm{N}$ per treatment was mixed in the soil just before planting. In wheat, three to four irrigations were given at CRI, MT, flowering, or grain filling stages using both well and canal water. While CRI stage coincided with time of first irrigation 3 weeks after planting wheat, MT stage varied in the 3 years, depending primarily on the date of planting and the climate. Dates of planting, harvesting, and fertilizer application for the experiments conducted in the three seasons are given in Table 2. Weeds, pests, and diseases were controlled as required.

Crops were harvested by hand at ground level at maturity. Grain and straw yields were recorded from an area (12 to $13.4 \mathrm{~m}^{2}$ ) located at the center of each plot. Grains were separated from straw using a plot thresher, dried in a batch grain dryer, and weighed. Grain moisture was determined immediately after weighing, and subsamples were dried in an oven at $65{ }^{\circ} \mathrm{C}$ for $48 \mathrm{~h}$. Grain weights were expressed at $120 \mathrm{~g} \mathrm{~kg}^{-1}$ water content. Straw yields were expressed on oven-dry basis.

Plant Sampling and Analysis

Grain and straw subsamples were dried at $70{ }^{\circ} \mathrm{C}$ and finely ground to pass through a $0.5 \mathrm{~mm}$ sieve. Nitrogen content in grain and straw was determined by digesting the samples in sulfuric acid, followed by analysis for total $\mathrm{N}$ by a micro-

Table 2 Dates of planting, harvesting, and fertilizer application in the experiments conducted during three wheat seasons

\begin{tabular}{|c|c|c|c|}
\hline \multirow[t]{2}{*}{ Crop management event } & \multicolumn{3}{|c|}{ Experiment conducted in } \\
\hline & 2006-2007 & 2007-2008 & 2009-2010 \\
\hline Planting & $02 / 11 / 2006$ & $15 / 11 / 2007$ & $11 / 11 / 2009$ \\
\hline Harvesting & $25 / 04 / 2007$ & $05 / 05 / 2008$ & $26 / 04 / 2010$ \\
\hline $\begin{array}{l}\text { Basal fertilizer } \\
\text { application }\end{array}$ & $02 / 11 / 2006$ & $15 / 11 / 2007$ & $11 / 11 / 2009$ \\
\hline $\begin{array}{l}\text { Crown root initiation } \\
\text { stage fertilizer } \\
\text { application }\end{array}$ & $29 / 11 / 2006$ & $06 / 12 / 2007$ & $04 / 12 / 2009$ \\
\hline $\begin{array}{l}\text { Maximum tillering } \\
\text { stage fertilizer } \\
\text { application }\end{array}$ & 04/01/2007 & $11 / 01 / 2008$ & $13 / 01 / 2010$ \\
\hline
\end{tabular}

Kjeldahl method [28]. The $\mathrm{N}$ in grain plus that in straw was taken as the measure of total $\mathrm{N}$ uptake.

\section{Chlorophyll Meter and GreenSeeker Optical Sensor Measurements}

Chlorophyll meter readings were taken with a Minolta SPAD-502 chlorophyll meter (SPAD meter). Ten plants per plot were read, consisting of three readings per plant. Spectral reflectance expressed as NDVI was measured using a handheld GreenSeeker ${ }^{\mathrm{TM}}$ optical sensor unit (NTech industries incorporation, Ukiah, CA, USA). The sensor unit has self-contained illumination in both the red $(656 \mathrm{~nm}$ with $\sim 25 \mathrm{~nm}$ full width half magnitude (FWHM)) and near infra red (NIR) (774 with $\sim 25 \mathrm{~nm}$ FWHM) bands (http://www. ntechindustries.com/datasheets.php, confirmed on 09 August 2012). The device uses a patented technique to measure the fraction of the emitted light in the sensed area that is returned to the sensor (crop reflectance) and calculates NDVI as: NDVI $=\left(F_{\mathrm{NIR}}-F_{\mathrm{RED}}\right) /\left(F_{\mathrm{NIR}}+F_{\mathrm{RED}}\right)$, where $F_{\text {NIR }}$ and $F_{\text {RED }}$ are, respectively, the fractions of emitted NIR and red radiation reflected back from the sensed area. The sensor outputs NDVI at a rate of ten readings per second. The sensor was passed over the crop at a height of $\sim 0.9 \mathrm{~m}$ above the crop canopy and oriented so that the $0.6 \mathrm{~m}$ sensed width was perpendicular to the row and centered over the row. Travel velocities were at a slow walking speed of $\sim 0.5 \mathrm{~m} \mathrm{~s}^{-1}$ resulting in NDVI readings averaged over distances of $0.05 \mathrm{~m}$.

The readings with both SPAD meter and GreenSee$\operatorname{ker}^{\mathrm{TM}}$ optical sensor were taken at MT stage in all the subplots irrespective of whether a fertilizer $\mathrm{N}$ dose of $30 \mathrm{~kg} \mathrm{ha}^{-1}$ was applied or not. The measurements were made just before applying the MT stage fertilizers $\mathrm{N}$ dose.

\section{Data Analysis}

Analysis of variance was performed on yield parameters to determine effects of cultivars, $\mathrm{N}$ management treatments, and their interaction using IRRISTAT version 5.0 (International Rice Research Institute, Philippines). Mean comparison was performed based on the least significant difference (LSD) test at the 0.05 probability level. Simple 
linear regression analysis was performed to study the response of wheat to $\mathrm{N}$ application at MT.

Percent grain yield response of wheat to application of $30 \mathrm{~kg} \mathrm{~N} \mathrm{ha}^{-1}$ at MT stage was calculated at different levels of $\mathrm{N}$ application at planting + CRI stages:

Percent grain yield response $=100$

$\times$ (grain yield in plots receiving $30 \mathrm{~kg} \mathrm{~N} \mathrm{ha}^{-1}$ at MT

- grain yield of wheat in plots receiving no $\mathrm{N}$ at MT)

/grain yield of wheat in plots receiving no $\mathrm{N}$ at MT.

\section{Results and Discussion}

By applying fertilizer $\mathrm{N}$ to wheat in two equal split doses at planting and along with first irrigation at CRI stage (general recommendation), significant increase in grain yield was recorded up to $100 \mathrm{~kg} \mathrm{~N} \mathrm{ha}^{-1}$ for wheat cultivar WH543 during 2006-2007 season and WH542 during 2007-2008 wheat season (Tables 3, 4, 5). For wheat cultivar WH343 during 2007-2008 and cultivars DBW17 and PBW550 during 2009-2010, significant increases in yield were recorded up to $120 \mathrm{~kg} \mathrm{~N} \mathrm{ha}^{-1}$. As blanket recommendation of applying $120 \mathrm{~kg} \mathrm{~N} \mathrm{ha}^{-1}$ in the region [27] has been formulated in such a way that there does not occur deficiency of $\mathrm{N}$ in any field, significant responses only up to $100 \mathrm{~kg} \mathrm{~N} \mathrm{ha}^{-1}$ in some years, fields, and cultivars were not unexpected. The data in Tables 3, 4, and 5 also suggest that by applying fertilizer $\mathrm{N}$ as per general recommendation, no significant yield increase can be achieved beyond $120 \mathrm{~kg} \mathrm{~N} \mathrm{ha}{ }^{-1}$.

By applying an additional dose of $30 \mathrm{~kg} \mathrm{~N} \mathrm{ha}^{-1}$ at MT stage, a significant increase in the yield of wheat grain was observed over that obtained by applying two equal $\mathrm{N}$ doses as per general recommendation up to $120 \mathrm{~kg} \mathrm{~N} \mathrm{ha}^{-1}$ in 2006-2007 and 2007-2008 seasons (Tables 3,4) and up to $100 \mathrm{~kg} \mathrm{~N} \mathrm{ha}^{-1}$ in 2009-2010 wheat season. Increase in the yield of wheat by applying $30 \mathrm{~kg} \mathrm{~N} \mathrm{ha}^{-1}$ at MT stage ranged from 0.87 to $1.22 \mathrm{t} \mathrm{ha}^{-1}, 0.30$ to 0.41 , and 0.08 to $0.41 \mathrm{~kg} \mathrm{~N} \mathrm{ha}^{-1}$ on the top of 0,100 , and $120 \mathrm{~kg} \mathrm{~N} \mathrm{ha}^{-1}$ fertilizer $\mathrm{N}$ applications as per general recommendation. Significant increase in total $\mathrm{N}$ uptake due to application of $30 \mathrm{~kg} \mathrm{~N} h a^{-1}$ at MT stage over and above $100 \mathrm{~kg} \mathrm{~N} \mathrm{ha}^{-1}$ during all the years and all the wheat cultivars proves that increase in grain yield was due to improved $\mathrm{N}$ nutrition (Tables 3, 4, 5). Significant increase in N uptake due to MT fertilizer $\mathrm{N}$ application was observed even when $120 \mathrm{~kg} \mathrm{~N}$ $\mathrm{ha}^{-1}$ was applied to wheat cultivars PBW343 and WH542 during 2006-2007 and 2007-2008 seasons.

The data reported in Tables 3, 4, 5 are in line with already published research on $\mathrm{N}$ nutrition of wheat. Recently, Varinderpal-Singh et al. [25] found that a fertilizer $\mathrm{N}$ management strategy based on application of
$25 \mathrm{~kg} \mathrm{~N} \mathrm{ha}^{-1}$ at planting, $45 \mathrm{~kg} \mathrm{~N} \mathrm{ha}^{-1}$ at first irrigation, and a dose of 30 or $45 \mathrm{~kg} \mathrm{~N}$ ha $^{-1}$ at second irrigation stage depending on color of the leaf resulted in high yield levels as well as improved agronomic and recovery efficiencies of fertilizer N. In Mexico, Ortiz-Monasterio et al. [17] observed that a three-way-split application of fertilizer $\mathrm{N}$ to wheat with one third at planting, one third at Feekes six stage (Zadok's scale Z31), and one third at Feekes eight (flag leaf just visible, Z37) resulted in optimum grain yield of wheat. In a study carried out by international atomic energy agency on irrigated wheat in ten countries, it was found that most of the $\mathrm{N}$ should be applied by Feekes six stage to maximize grain yield, and $\mathrm{N}$ application should not be delayed beyond Feekes eight stage [10]. Nitrogen uptake of irrigated wheat proceeds very slowly until tillering begins, and $\mathrm{N}$ flux $\left(\mathrm{kg} \mathrm{N} \mathrm{ha}^{-1} \mathrm{day}^{-1}\right)$ increases to a maximum around Feekes six stage [7], which coincides with maximum tillering stage at second irrigation. BijaySingh et al. [5] observed that high $\mathrm{N}$ use efficiency in irrigated wheat can be achieved by applying moderate amount of fertilizer $\mathrm{N}$ at planting and MT stages and sensor-guided fertilizer $\mathrm{N}$ dose at Feekes $5-6$ or 7-8 stages of wheat.

The SPAD-502 chlorophyll meter estimates the amount of chlorophyll present by measuring the amount of light that is transmitted through a leaf. In essence, it determines the leaf greenness. Lopez-Bellido et al. [15] observed the potential of SPAD meter in predicting fertilizer $\mathrm{N}$ requirements in wheat. The Fig. 1 shows a plot of SPAD meter values recorded at MT stage of all the five wheat cultivars (PBW343, WH542, DBW17, PBW550) grown during the three seasons as a function of fertilizer $\mathrm{N}$ applied up to this stage. The dose of $30 \mathrm{~kg} \mathrm{~N} \mathrm{ha}^{-1}$ was applied only after recording the greenness of leaves using SPAD meter. The data in Fig. 1 reveal that leaf greenness is a function of $\mathrm{N}$ applied through fertilizers. Irrespective of wheat cultivar and year, application of $100-120 \mathrm{~kg} \mathrm{~N} \mathrm{ha}^{-1}$ of fertilizer as per general recommendation resulted in relatively greener leaf colors than those observed with application of low fertilizer dose at MT stage.

Chlorophyll is the pigment responsible for the green color of plants and is the light capturing molecule in photosynthesis-the main metabolic processes determining crop production. Leaf chlorophyll content has been positively correlated with photosynthetic capacity [1]. Gregersen et al. [8] reported a positive correlation between delayed crop senescence and grain yield of wheat and indicated that the potential for higher plant productivity from greener leaves may be due to a longer period of active photosynthesis. Nutrients are mobilized from the older leaves to the younger leaves and eventually to the flag leaf, which contributes the majority of the nutrients and photo-assimilates used for grain filling [8]. Thus during crop growth stages approaching 
Table 3 Grain yield and N uptake of wheat variety WH343 as influenced by application of different N levels at planting and crown root initiation (CRI) stages (Main plots) and 0 or $30 \mathrm{~kg} \mathrm{~N} \mathrm{ha}^{-1}$ at maximum tillering (MT) stage (Subplots) at Ludhiana in 2006-2007

\begin{tabular}{|c|c|c|c|c|c|c|}
\hline \multicolumn{2}{|l|}{ Treatment } & \multicolumn{3}{|c|}{ Fertilizer $\mathrm{N}$ application $\left(\mathrm{kg} \mathrm{N} \mathrm{ha}^{-1}\right)$} & \multirow{2}{*}{$\begin{array}{l}\text { Grain yield } \\
\left(\mathrm{t} \mathrm{ha}^{-1}\right)\end{array}$} & \multirow{2}{*}{$\begin{array}{l}\text { Nitrogen uptake } \\
\left(\mathrm{kg} \mathrm{N} \mathrm{ha}^{-1}\right)\end{array}$} \\
\hline Main plots & Subplots & Planting $(02 / 11 / 2006)$ & CRI (29/11/2006) & MT (04/01/2007) & & \\
\hline \multirow[t]{2}{*}{ M1: $0 \mathrm{~kg} \mathrm{~N} \mathrm{ha}{ }^{-1}$} & $\mathrm{~S} 1: 0 \mathrm{~kg} \mathrm{~N} \mathrm{ha}^{-1}$ & 0 & 0 & 0 & 1.23 & 25.7 \\
\hline & S2: $30 \mathrm{~kg} \mathrm{~N} \mathrm{ha}^{-1}$ & 0 & 0 & 30 & 2.45 & 56.1 \\
\hline \multirow[t]{2}{*}{ M2: $60 \mathrm{~kg} \mathrm{~N} \mathrm{ha}^{-1}$} & $\mathrm{~S} 1: 0 \mathrm{~kg} \mathrm{~N} \mathrm{ha}{ }^{-1}$ & 30 & 30 & 0 & 3.52 & 81.2 \\
\hline & S2: $30 \mathrm{~kg} \mathrm{~N} \mathrm{ha}^{-1}$ & 30 & 30 & 30 & 4.19 & 99.0 \\
\hline \multirow[t]{2}{*}{ M3: $80 \mathrm{~kg} \mathrm{~N} \mathrm{ha}^{-1}$} & $\mathrm{~S} 1: 0 \mathrm{~kg} \mathrm{~N} \mathrm{ha}{ }^{-1}$ & 40 & 40 & 0 & 3.84 & 88.2 \\
\hline & S2: $30 \mathrm{~kg} \mathrm{~N} \mathrm{ha}^{-1}$ & 40 & 40 & 30 & 4.67 & 111.6 \\
\hline \multirow[t]{2}{*}{ M4: $100 \mathrm{~kg} \mathrm{~N} \mathrm{ha}^{-1}$} & S1: $0 \mathrm{~kg} \mathrm{~N} \mathrm{ha}^{-1}$ & 50 & 50 & 0 & 4.57 & 109.0 \\
\hline & $\mathrm{S} 2: 30 \mathrm{~kg} \mathrm{~N} \mathrm{ha}^{-1}$ & 50 & 50 & 30 & 4.98 & 118.9 \\
\hline \multirow[t]{2}{*}{ M5: $120 \mathrm{~kg} \mathrm{~N} \mathrm{ha}^{-1}$} & S1: $0 \mathrm{~kg} \mathrm{~N} \mathrm{ha}^{-1}$ & 60 & 60 & 0 & 4.77 & 115.2 \\
\hline & $\mathrm{S} 2: 30 \mathrm{~kg} \mathrm{~N} \mathrm{ha}^{-1}$ & 60 & 60 & 30 & 5.18 & 139.3 \\
\hline \multirow{3}{*}{\multicolumn{2}{|c|}{ Least significant difference $(p=0.05)$}} & & Main & & 0.214 & 6.36 \\
\hline & & & Sub & & 0.176 & 3.97 \\
\hline & & & Main $\times$ Sub & & 0.367 & 9.61 \\
\hline
\end{tabular}

Table 4 Grain yield and N uptake of wheat cultivars WH343 and WH542 as influenced by application of different N levels at planting and crown root initiation (CRI) stages (Main plots) and 0 or $30 \mathrm{~kg} \mathrm{~N} \mathrm{ha}^{-1}$ at maximum tillering (MT) stage (Subplots) at Ludhiana in 2007-2008

\begin{tabular}{|c|c|c|c|c|c|c|c|c|}
\hline \multicolumn{2}{|l|}{ Treatment } & \multicolumn{3}{|c|}{ Fertilizer $\mathrm{N}$ application $\left(\mathrm{kg} \mathrm{N} \mathrm{ha}^{-1}\right)$} & \multicolumn{2}{|c|}{ Cultivar WH343 } & \multicolumn{2}{|c|}{ Cultivar WH542 } \\
\hline Main plots & Subplots & $\begin{array}{l}\text { Planting } \\
(15 / 11 / 2007)\end{array}$ & $\begin{array}{l}\text { CRI } \\
(06 / 12 / 2007)\end{array}$ & $\begin{array}{l}\text { MT } \\
(11 / 01 / 2008)\end{array}$ & $\begin{array}{l}\text { Grain } \\
\text { yield } \\
\left(\mathrm{t} \mathrm{ha}^{-1}\right)\end{array}$ & $\begin{array}{l}\text { Total } \mathrm{N} \\
\text { uptake } \\
\left(\mathrm{kg} \mathrm{N} \mathrm{ha}^{-1}\right)\end{array}$ & $\begin{array}{l}\text { Grain } \\
\text { yield } \\
\left(\mathrm{t} \mathrm{ha}{ }^{-1}\right)\end{array}$ & $\begin{array}{l}\text { Total } \mathrm{N} \\
\text { uptake } \\
\left(\mathrm{kg} \mathrm{N} \mathrm{ha}^{-1}\right)\end{array}$ \\
\hline \multirow[t]{2}{*}{ M1: $0 \mathrm{~kg} \mathrm{~N} \mathrm{ha}^{-1}$} & S1: $0 \mathrm{~kg} \mathrm{~N} \mathrm{ha}^{-1}$ & 0 & 0 & 0 & 1.51 & 30.0 & 1.63 & 29.6 \\
\hline & $\mathrm{S} 2: 30 \mathrm{~kg} \mathrm{~N} \mathrm{ha}^{-1}$ & 0 & 0 & 30 & 2.54 & 48.9 & 2.63 & 50.0 \\
\hline \multirow[t]{2}{*}{ M2: $60 \mathrm{~kg} \mathrm{~N} \mathrm{ha}^{-1}$} & S1: $0 \mathrm{~kg} \mathrm{~N} \mathrm{ha}^{-1}$ & 30 & 30 & 0 & 3.40 & 66.8 & 3.60 & 69.5 \\
\hline & S2: $30 \mathrm{~kg} \mathrm{~N} \mathrm{ha}^{-1}$ & 30 & 30 & 30 & 4.11 & 90.2 & 4.11 & 83.9 \\
\hline \multirow[t]{2}{*}{ M3: $80 \mathrm{~kg} \mathrm{~N} \mathrm{ha}^{-1}$} & S1: $0 \mathrm{~kg} \mathrm{~N} \mathrm{ha}^{-1}$ & 40 & 40 & 0 & 4.04 & 81.2 & 3.78 & 80.0 \\
\hline & $\mathrm{S} 2: 30 \mathrm{~kg} \mathrm{~N} \mathrm{ha}^{-1}$ & 40 & 40 & 30 & 4.46 & 100.4 & 4.41 & 105.4 \\
\hline \multirow[t]{2}{*}{ M4: $100 \mathrm{~kg} \mathrm{~N} \mathrm{ha}^{-1}$} & S1: $0 \mathrm{~kg} \mathrm{~N} \mathrm{ha}^{-1}$ & 50 & 50 & 0 & 4.13 & 94.2 & 4.20 & 96.0 \\
\hline & S2: $30 \mathrm{~kg} \mathrm{~N} \mathrm{ha}^{-1}$ & 50 & 50 & 30 & 4.52 & 107.0 & 4.52 & 113.2 \\
\hline \multirow[t]{2}{*}{ M5: $120 \mathrm{~kg} \mathrm{~N} \mathrm{ha}^{-1}$} & S1: $0 \mathrm{~kg} \mathrm{~N} \mathrm{ha}^{-1}$ & 60 & 60 & 0 & 4.47 & 104.0 & 4.29 & 107.7 \\
\hline & S2: $30 \mathrm{~kg} \mathrm{~N} \mathrm{ha}^{-1}$ & 60 & 60 & 30 & 4.76 & 121.2 & 4.52 & 111.1 \\
\hline \multirow{3}{*}{\multicolumn{2}{|c|}{ Least significant difference $(p=0.05)$}} & & Main & & 0.193 & 4.03 & 0.286 & 7.90 \\
\hline & & & Sub & & 0.096 & 2.75 & 0.084 & 2.48 \\
\hline & & & Main $\times$ Sub & & 0.213 & 6.14 & 0.188 & 5.54 \\
\hline
\end{tabular}

senescence, the leaf greenness as measured by SPAD meter should be closely related to the grain yield to be recorded at maturity. According to Vidal et al. [26], SPAD meter readings of leaves at Zadok stages 45 and 69 [29] accounted for 85 and $72 \%$ of variation in grain yield, respectively. The SPAD values 40 and 45 were observed to be the lower and upper limits, respectively.

In the two graphs in Fig. 2, grain yield of wheat obtained at maturity is plotted against measurements made by SPAD meter and GreenSeeker optical sensor at MT stage of wheat before applying the dose of $30 \mathrm{~kg} \mathrm{~N} \mathrm{ha}^{-1}$. In the case of
GreenSeeker optical sensor, in-season estimate of yield (INSEY) determined by dividing the NDVI by number of growing degree days from planting to sensing, has been plotted against the grain yield of wheat. These relationships worked out using data from four wheat cultivars grown during three seasons turned out to be statistically significant $\left(R^{2}=0.85\right.$ for SPAD readings and $R^{2}=0.57$ for INSEY at $n=75$ ). The linear relations suggest that grain yield of wheat was determined by the level of greenness of the leaves at MT stage-whether measured by chlorophyll meter (SPAD value) or GreenSeeker optical sensor (INSEY). 
Table 5 Grain yield and N uptake of wheat cultivars DBW17 and PBW550 as influenced by application of different N levels at planting and crown root initiation (CRI) stages (Main plots) and 0 or $30 \mathrm{~kg} \mathrm{~N} \mathrm{ha}^{-1}$ at maximum tillering (MT) stage (Subplots) at Ludhiana in 2009-2010

\begin{tabular}{|c|c|c|c|c|c|c|c|c|}
\hline \multicolumn{2}{|l|}{ Treatment } & \multicolumn{3}{|c|}{ Fertilizer $\mathrm{N}$ application $\left(\mathrm{kg} \mathrm{N} \mathrm{ha}^{-1}\right)$} & \multicolumn{2}{|c|}{ Cultivar DBW17 } & \multicolumn{2}{|c|}{ Cultivar PBW550 } \\
\hline Main plots & Subplots & $\begin{array}{l}\text { Planting } \\
(11 / 11 / 2009)\end{array}$ & $\begin{array}{l}\text { CRI } \\
(04 / 12 / 2009)\end{array}$ & $\begin{array}{l}\text { MT } \\
(13 / 01 / 2010)\end{array}$ & $\begin{array}{l}\text { Grain } \\
\text { yield } \\
\left(\mathrm{t} \mathrm{ha}^{-1}\right)\end{array}$ & $\begin{array}{l}\text { Total N } \\
\text { uptake } \\
\left(\mathrm{kg} \mathrm{N} \mathrm{ha}^{-1}\right)\end{array}$ & $\begin{array}{l}\text { Grain yield } \\
\left(\mathrm{t} \mathrm{ha}^{-1}\right)\end{array}$ & $\begin{array}{l}\text { Total N uptake } \\
\left(\mathrm{kg} \mathrm{N} \mathrm{ha}^{-1}\right)\end{array}$ \\
\hline \multirow[t]{2}{*}{$\mathrm{M} 1: 0 \mathrm{~kg} \mathrm{~N} \mathrm{ha}{ }^{-1}$} & S1: $0 \mathrm{~kg} \mathrm{~N} \mathrm{ha}^{-1}$ & 0 & 0 & 0 & 2.53 & 53.9 & 2.43 & 51.6 \\
\hline & S2: $30 \mathrm{~kg} \mathrm{~N} \mathrm{ha}^{-1}$ & 0 & 0 & 30 & 3.43 & 78.2 & 3.30 & 73.1 \\
\hline \multirow[t]{2}{*}{ M2: $60 \mathrm{~kg} \mathrm{~N} \mathrm{ha}^{-1}$} & S1: $0 \mathrm{~kg} \mathrm{~N} \mathrm{ha}^{-1}$ & 30 & 30 & 0 & 4.05 & 94.8 & 3.97 & 93.2 \\
\hline & $\mathrm{S} 2: 30 \mathrm{~kg} \mathrm{~N} \mathrm{ha}^{-1}$ & 30 & 30 & 30 & 4.62 & 114.3 & 4.64 & 111.5 \\
\hline \multirow[t]{2}{*}{ M3: $80 \mathrm{~kg} \mathrm{~N} \mathrm{ha}^{-1}$} & $\mathrm{~S} 1: 0 \mathrm{~kg} \mathrm{~N} \mathrm{ha}^{-1}$ & 40 & 40 & 0 & 4.34 & 100.9 & 4.20 & 101.0 \\
\hline & $\mathrm{S} 2: 30 \mathrm{~kg} \mathrm{~N} \mathrm{ha}^{-1}$ & 40 & 40 & 30 & 4.78 & 121.9 & 4.62 & 112.0 \\
\hline M4: 100 & S1: $0 \mathrm{~kg} \mathrm{~N} \mathrm{ha}^{-1}$ & 50 & 50 & 0 & 4.66 & 114.7 & 4.54 & 115.4 \\
\hline $\mathrm{kg} \mathrm{N} \mathrm{ha}^{-1}$ & S2: $30 \mathrm{~kg} \mathrm{~N} \mathrm{ha}^{-1}$ & 50 & 50 & 30 & 4.96 & 126.3 & 4.86 & 122.2 \\
\hline \multirow[t]{2}{*}{ M5: $120 \mathrm{~kg} \mathrm{~N} \mathrm{ha}^{-1}$} & $\mathrm{~S} 1: 0 \mathrm{~kg} \mathrm{~N} \mathrm{ha}^{-1}$ & 60 & 60 & 0 & 4.93 & 127.3 & 4.90 & 120.7 \\
\hline & $\mathrm{S} 2: 30 \mathrm{~kg} \mathrm{~N} \mathrm{ha}^{-1}$ & 60 & 60 & 30 & 5.04 & 127.9 & 4.98 & 122.4 \\
\hline \multirow{3}{*}{\multicolumn{2}{|c|}{ Least significant difference $(p=0.05)$}} & & Main & & 0.109 & 4.66 & 0.022 & 6.69 \\
\hline & & & Sub & & 0.063 & 2.64 & 0.053 & 2.66 \\
\hline & & & Main $\times$ Sub & & 0.141 & 5.92 & 0.119 & 5.95 \\
\hline
\end{tabular}

Variation in wheat grain yield was found to be as large as $3 \mathrm{t}$ ha $^{-1}$ between SPAD readings of 30 and 45 of the wheat leaves at MT stage.

In Fig. 3, data pertaining to grain yield response to $\mathrm{N}$ application at MT recorded for the four wheat cultivars grown in three seasons were regressed against SPAD readings and INSEY values at MT. Significant negative relationships with $R^{2}=0.65(n=75)$ for SPAD readings

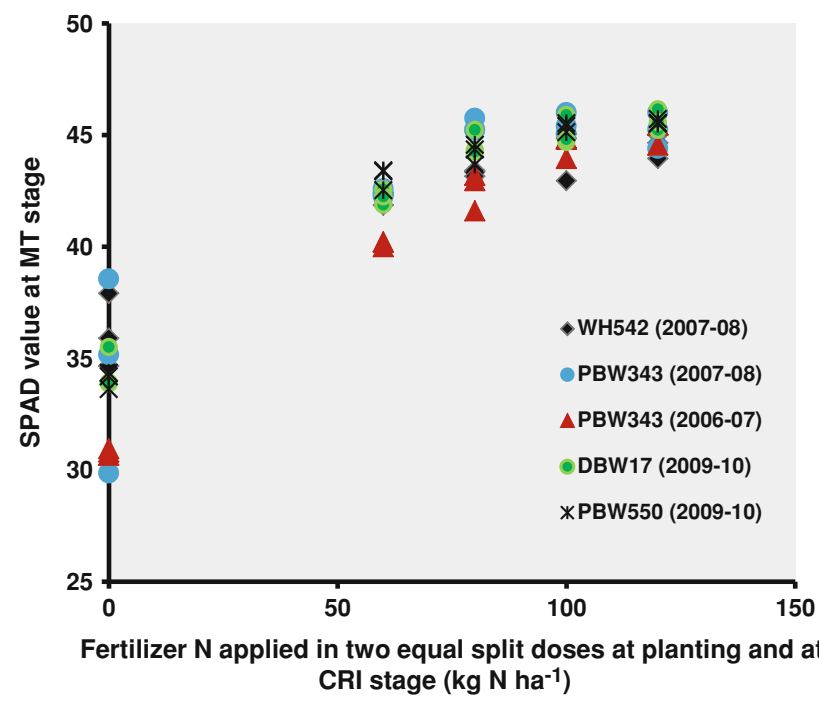

Fig. 1 Response of wheat cultivars PBW343, WH542, DBW17, and PBW550 in terms of leaf greenness at maximum tillering (MT) stage as measured by SPAD meter to increasing dose of nitrogen applied in two equal split doses at planting and crown root initiation (CRI) stage at Ludhiana during 2006-2007, 2007-2008, and 2009-2010 seasons. (Color figure online) and $R^{2}=0.58(n=75)$ for INSEY (worked out from GreenSeeker optical sensor measurements) were observed. These plots show that at MT stage, SPAD values $\leq 44.6$, or INSEY values $\leq 0.012$, application of $30 \mathrm{~kg} \mathrm{~N}^{-1}$ can increase yield by $0.4 \mathrm{t} \mathrm{ha}^{-1}$ or more. Below these critical limits, the extent of response increased linearly with decreasing SPAD or INSEY values at MT. When per cent wheat grain yield response expressed as: $100 \times$ (grain yield in plots receiving $30 \mathrm{~kg} \mathrm{~N} \mathrm{ha}^{-1}$ at MT-grain yield of wheat in plots receiving no $\mathrm{N}$ at $\mathrm{MT}) \div$ grain yield of wheat in plots receiving no $\mathrm{N}$ at MT, was plotted against the SPAD meter or INSEY readings at MT stage (Fig. 4), it revealed that by applying $30 \mathrm{~kg} \mathrm{~N} \mathrm{ha}^{-1}$ when color of the wheat leaves was equivalent to or less than SPAD value of 42.2 or INSEY values of 0.105 , a grain yield response of $20 \%$ or more can be expected. Grain yield response to $\mathrm{N}$ application at MT regressed against SPAD readings at MT revealed that an application of $30 \mathrm{~kg} \mathrm{~N}^{-1}$ will increase wheat yield by 1.0 or $0.5 \mathrm{t} \mathrm{ha}^{-1}$ when color of the wheat leaves was equivalent to or less than SPAD value of 32.5 or 42.5 , respectively. Robust regression between grain yield response and INSEY values revealed that application of $30 \mathrm{~kg} \mathrm{~N} \mathrm{ha}^{-1}$ at MT will lead to a grain yield increase by 1.0 or $0.5 \mathrm{t} \mathrm{ha}^{-1}$ if INSEY values were found to be 0.005 or 0.011 , respectively. The regression coefficients based on four wheat cultivars grown in three wheat seasons for predicting per cent yield increase due to application of $30 \mathrm{~kg} \mathrm{~N} \mathrm{ha}{ }^{-1}$ turned out to be as high as $R^{2}=0.77$ $(n=75)$ for SPAD values and $R^{2}=0.61(n=75)$ for INSEY. As the relationships between grain yield response to $\mathrm{N}$ applied at MT stage and INSEY values as computed 
from GreenSeeker optical sensor measurements were similar to those obtained for SPAD values (Figs. 3, 4), both SPAD meter and GreenSeeker optical sensor can be used with equal effectiveness for guiding fertilizer $\mathrm{N}$ application to wheat at MT stage.

Results obtained in the present study provide strong evidence that current fertilizer $\mathrm{N}$ recommendations are inadequate for maintaining high yields of wheat. Uniform blanket applications of fertilizer $\mathrm{N}$ discount the fact that $\mathrm{N}$ supplies from the soil, crop $\mathrm{N}$ uptake, and response to $\mathrm{N}$ are not the same spatially [11]. Peltonen et al. [19] observed environmental as well as economic advantages for chlorophyll content-based fertilizer $\mathrm{N}$ recommendations in wheat. Arregui et al. [2] used normalized relationships of relative yield and grain $\mathrm{N}$ concentration with SPAD meter readings following a quadratic model and Cate-Nelson statistical procedure. The SPAD meter readings at Zadok stage 37 were helpful in identifying treatments that would respond to a third application of $\mathrm{N}$ fertilizer in $91 \%$ of the cases. The SPAD meter measurements at Zadok stages 37-41 (maximum number of florets per ear primordium)
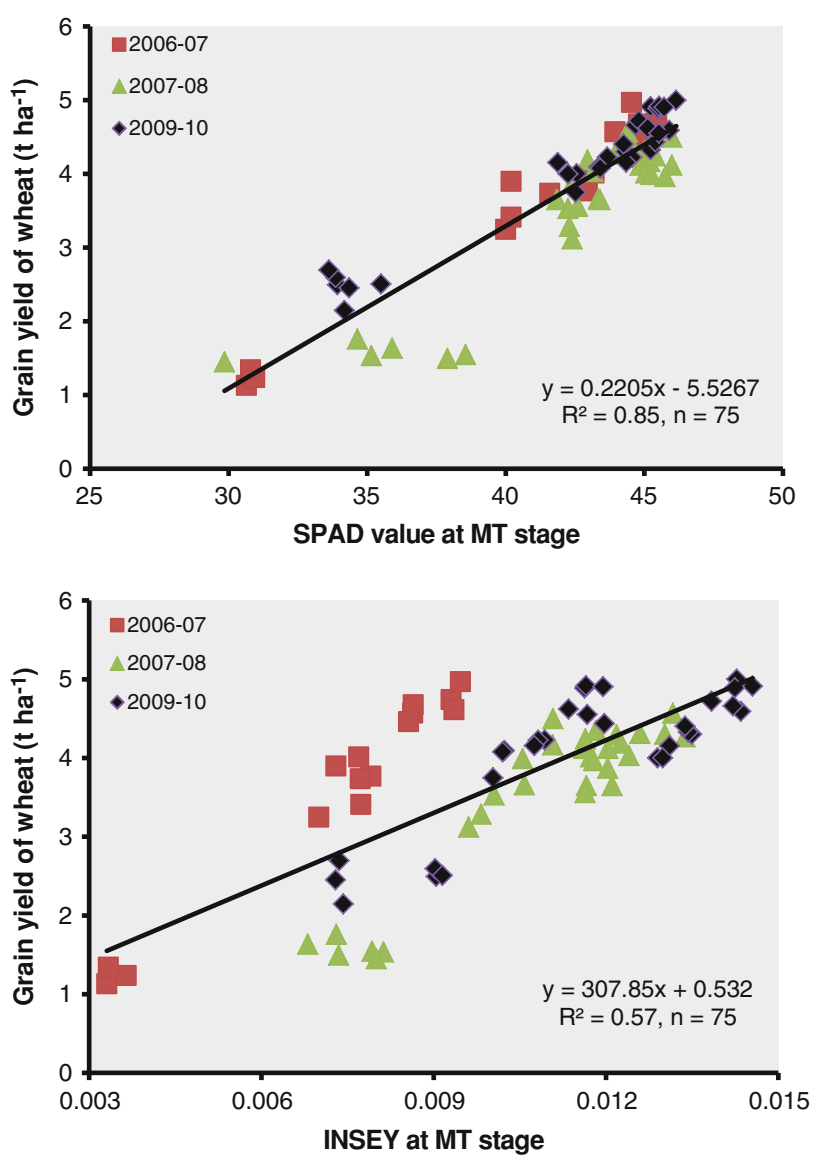

Fig. 2 Relationship between grain yields of wheat (cultivars PBW343, WH542, DBW17, PBW550) with different pre-plant $\lessgtr$ (CRI) $\mathrm{N}$ levels and SPAD values or INSEY values measured by GreenSeeker recorded at (MT) stage at Ludhiana during 2006-2007, 2007-2008, and 2009-2010 seasons and Zadok stages 52-58 (pollen grains on well-developed stigmatic hairs) were useful in identifying wheat cultivars responsive or non-responsive to $\mathrm{N}$ application. Some recent studies on wheat $[4,5,25]$ grown in the IGP have shown that a dose of fertilizer $\mathrm{N}$ needs to be applied at MT stage as per need of the crop to achieve high fertilizer $\mathrm{N}$ use efficiency. However, the criteria to decide application of fertilizer $\mathrm{N}$ dose were coupled with a well-defined fertilizer $\mathrm{N}$ management schedule at planting and at CRI stages. The present investigation provides a criterion for deciding fertilizer $\mathrm{N}$ application at MT stage of irrigated wheat irrespective of fertilizer $\mathrm{N}$ applications made at earlier stages. Bijay-Singh et al. [4] observed that wheat responded to top dressing of $30 \mathrm{~kg} \mathrm{~N}^{-1}$ when the $\mathrm{SPAD}$ reading at MT was less than 44 and observed a $20 \%$ yield increase at an SPAD value of 42 or less. Hussain et al. [9] determined a critical SPAD value of 42 for guiding need-based $\mathrm{N}$ top dressing in wheat in IGP in Pakistan. Maiti and Das [16], however, found 37 as threshold SPAD value for guiding fertilizer $\mathrm{N}$ applications to wheat in the eastern IGP where
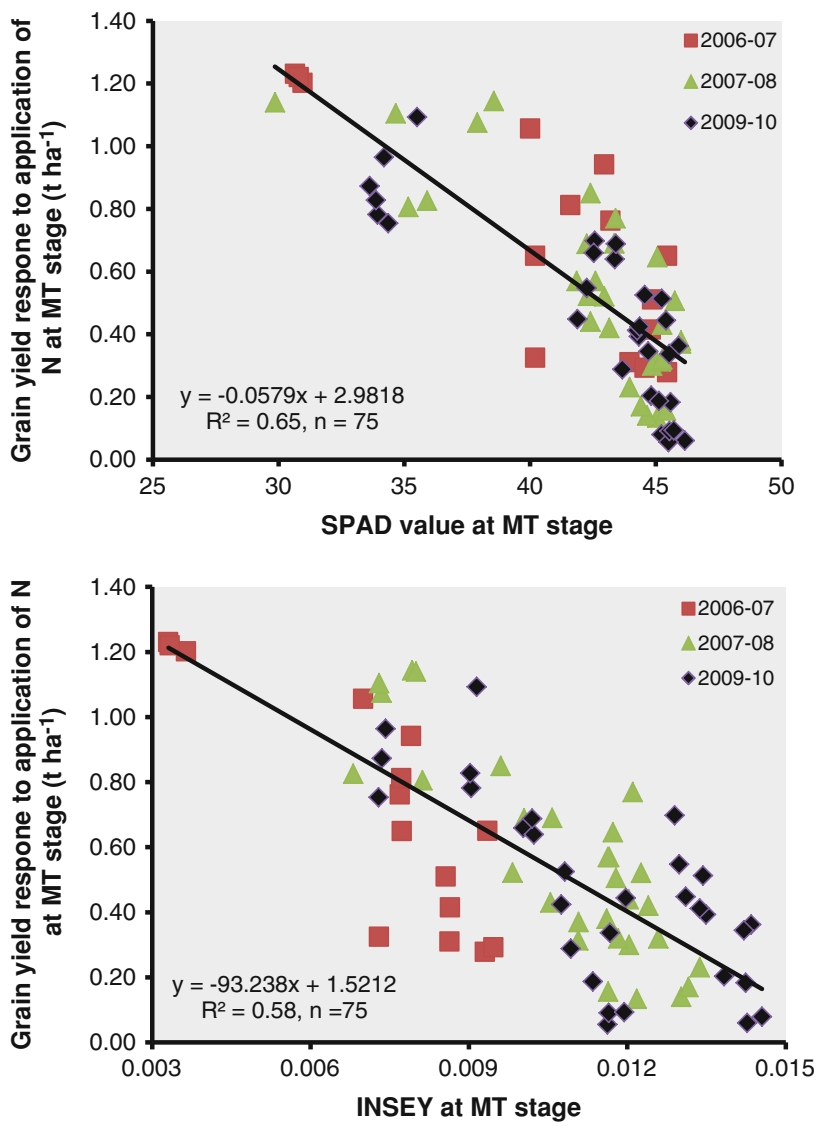

Fig. 3 Relationship between grain yield response of wheat (cultivars PBW343, WH542, DBW17, PBW550) to $30 \mathrm{~kg} \mathrm{~N} / \mathrm{ha}$ applied at (MT) and SPAD values recorded by chlorophyll meter or INSEY values computed from NDVI measured by GreenSeeker optical sensor at MT before N application at Ludhiana during 2006-2007, 2007-2008, and 2009-2010 seasons 

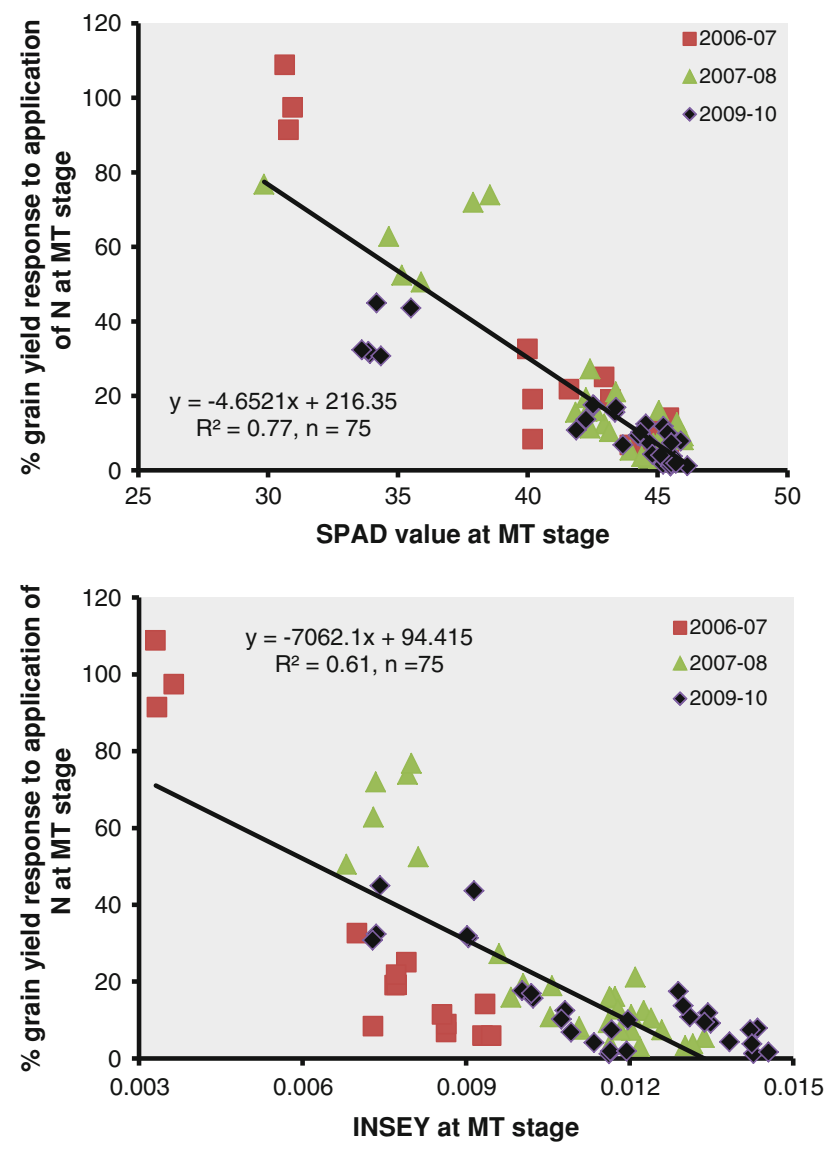

Fig. 4 Relationship between \% grain yield response of wheat (cultivars PBW343, WH542, DBW17, PBW550) to $30 \mathrm{~kg} \mathrm{~N} / \mathrm{ha}$ applied at maximum tillering (MT) and SPAD values recorded by chlorophyll meter or INSEY values computed from NDVI measured by GreenSeeker optical sensor at MT before $\mathrm{N}$ application at Ludhiana during 2006-2007, 2007-2008, and 2009-2010 seasons. Percent grain yield response $=100 \times$ (grain yield in plots receiving $30 \mathrm{~kg} \mathrm{~N} / \mathrm{ha}$ at MT '" grain yield of wheat in plots receiving no $\mathrm{N}$ at MT)/grain yield of wheat in plots receiving no $\mathrm{N}$ at MT

winters are mild and yields are relatively lower than those observed in western IGP where the present investigation has been carried out. As the criteria developed for deciding MT stage application of a fertilizer $\mathrm{N}$ dose in the present investigation are based on data generated for three wheat seasons using four cultivars grown over a vast area in the northwestern India, it should be useful for achieving high fertilizer $\mathrm{N}$ use efficiency in the western half of the IGP.

Acknowledgments The authors acknowledge the Indian council of agricultural research, New Delhi, India for providing funds under the National Professor Project to carry out this study.

\section{References}

1. Araus JI, Bort J, Ceccarelli S, Grando S (1997) Relationship between leaf structure and carbon isotope discrimination in field grown barley. Plant Physiol Bioch 35:533-541
2. Arregui LM, Lasa B, Lafarga A, Iraneta I, Barja E, Quemada M (2006) Evaluation of chlorophyll meters as tools for $\mathrm{N}$ fertilization in winter wheat under humid mediterranean conditions. Eur J Agron 24:140-148

3. Balasubramanian V, Adhya TK, Ladha JK (2012) http://ciat.cgiar. org/wp-content/uploads/2012/12/chapter_7_eco_efficiency.pdf. Accessed 10 Aug 2012

4. Bijay-Singh, Yadvinder-Singh, Ladha JK, Bronson KF, Balasubramanian V, Jagdeep-Singh, Khind CS (2002) Chlorophyll meter- and leaf color chart-based nitrogen management for rice and wheat in northwestern India. Agron J 94:821-829

5. Bijay-Singh, Sharma RK, Jaspreet-Kaur, Jat ML, Martin KL, Varinderpal-Singh, Yadvinder-Singh, Chandna P, Choudhary OP, Gupta RK, Thind HS, Uppal HS, Jagmohan-Singh, Khurana HS, Ajay-Kumar, Uppal RK, Vashistha M, Raun WR, Gupta RK (2011) Assessment of the nitrogen management strategy using an optical sensor for irrigated wheat. Agron Sust Dev 31:589-603. doi:10.1007/s13593-011-0005-5

6. Chaudhary TN, Katoch KK (1981) Fertiliser N management for wheat in coarse textured soils. Fert News 26(12):36-39

7. Doerge TA, Roth RI, Gardner BR (1991) Nitrogen fertilizer management in Arizona. College of agriculture, The University of Arizona, Tucson, p 87

8. Gregersen PL, Holm PB, Krupinska K (2008) Leaf senescence and nutrient remobilization in barley and wheat. Plant Biol 10: $37-49$

9. Hussain F, Zia MS, Akhtar ME, Yasin M (2003) Nitrogen management and use efficiency with chlorophyll meter and leaf colour chart. Pakistan J Soil Sci 22:1-10

10. IAEA (2000) Optimizing nitrogen fertilizer application in irrigated wheat: Results of a coordinated research project organized by the joint FAP/IAEA Division of Nuclear Techniques in Food and Agriculture 1994-1998, IAEA TECDOC-1164. International Atomic Energy Agency, Vienna, p 245

11. Inman D, Khosla R, Westfall DG, Reich R (2005) Nitrogen uptake across site specific management zones in irrigated corn production systems. Agron J 97:169-176

12. Keating BA, Carberry PS, Bindraban PS, Asseng S, Meinke H, Dixon J (2010) Eco-efficient agriculture: concepts, challenges, and opportunities. Crop Sci 50:109-119

13. Ladha JK, Dawe D, Pathak H, Padre AT, Yadav RL, YadvinderSingh, Bijay-Singh, Singh P, Kundu AL, Sakal R, Ram N, Regmi AP, Gami SK, Bhandari AL, Amin K, Yadav CR, Bhattarai EM, Gupta RK, Hobbs PR (2003) How extensive are yield declines in long-term rice-wheat experiments in Asia? Field Crops Res 81:159-180

14. Ladha JK, Pathak H, Krupnik TJ, Six J, van Kessel C (2005) Efficiency of fertilizer nitrogen in cereal production: retrospect and prospects. Adv Agron 87:85-156. doi:10.1016/S0065-2113 (05) $87003-8$

15. Lopez-Bellido RJ, Shepherd CE, Barraclough PB (2004) Predicting post-anthesis $\mathrm{N}$ requirements of bread wheat with a minolta SPAD meter. Eur J Agron 20:313-320

16. Maiti D, Das DK (2006) Management of nitrogen through the use of leaf colour chart (LCC) and soil plant analysis development (SPAD) in wheat under irrigated ecosystem. Arch Agron Soil Sci 52:105-112

17. Ortiz-Monasterio JIR, Sayre KD, Pena J, Fischer RA (1994) Improving the nitrogen use efficiency of irrigated spring wheat in the yaqui valley of Mexico. Trans 15th World Cong Soil Sci 5b:348-349

18. Pathak H, Li C, Wassman R, Ladha JK (2006) Simulation of nitrogen balance in rice-wheat systems of the Indo-Gangetic plains. Soil Sci Soc Am J 70:1612-1622

19. Peltonen J, Virtanen A, Haggren E (1995) Using a chlorophyll meter to optimize nitrogen fertilizer application for intensively managed small-grain cereals. J Agron Crop Sci 174:309-318 
20. Peñuelas J, Gamon JA, Fredeen AL, Merino J, Field CB (1994) Reflectance indices associated with physiological changes in nitrogen- and water-limited sunflower leaves. Remote Sens Environ 48:135-146. doi:10.1016/0034-4257(94)90136-8

21. Raun WR, Johnson GV, Stone ML, Solie JB, Lukina EV, Thomason WE, Schepers JS (2001) In-season prediction of potential grain yield in winter wheat using canopy reflectance. Agron J 93:131-138. doi:10.2134/agronj2001.931131x

22. Raun WR, Solie JB, Johnson GV, Stone ML, Mullen RW, Freeman KW, Thomason WE, Lukina EV (2002) Improving nitrogen use efficiency in cereal grain production with optical sensing and variable rate application. Agron J 94:815-820. doi: 10.2134/agronj2002.0815

23. Saharawat YS, Gathala M, Ladha JK, Malik RK, Singh S, Jat ML, Gupta RK, Pathak H, Singh K (2009) Evaluation and promotion of integrated crop and resource management in the rice-wheat system in north-west India. In: Ladha JK, YadvinderSingh, Erenstein O, Hardy B (eds) Integrated crop and resource management in the rice-wheat system of South Asia. international rice research institute (IRRI). Los Baños, Philippines, pp 133-150

24. Varinderpal-Singh, Bijay-Singh, Yadvinder-Singh, Thind HS, Gupta RK (2010) Need-based nitrogen management using the chlorophyll meter and leaf colour chart in rice and wheat in South Asia: a review. Nutr Cycl Agroecosyst 88:361-380. doi: 10.1007/s10705-010-9363-7

25. Varinderpal-Singh, Bijay-Singh, Yadvinder-Singh, Thind HS, Gobinder-Singh, Satwinderjit-Kaur, Kumar A, Vashistha M (2012) Establishment of threshold leaf colour greenness for needbased fertilizer nitrogen management in irrigated wheat (Triticum aestivum L.) using leaf colour chart. Field Crops Res 130:109-119. doi:10.1016/j.fcr.2012.02.005

26. Vidal I, Longeril L, Hétier JM (1999) Nitrogen uptake and chlorophyll meter measurements in spring wheat. Nutr Cycl Agroecosyst 55:1-6

27. Yadvinder-Singh, Bijay-Singh, Ladha JK, Singh JP, Choudhary OP (2007) Enhancing nitrogen use efficiency for sustainable ricewheat production system in the Indo-Gangetic plains of India. In: Abrol YP, Raghuram N, Sachdev MS (eds) Agricultural nitrogen use \& its environmental implications. IK International Publishing House Pvt Ltd, New Delhi, pp 139-164

28. Yoshida S, Forno DA, Cock DH, Gomez KA (1976) Laboratory manual for physiological studies of rice, 3rd edn. International Rice Research Institute, Los Baños

29. Zadoks JC, Chang TT, Konzak CF (1974) A decimal code for the growth of cereals. Weed Res 14:415-421 